
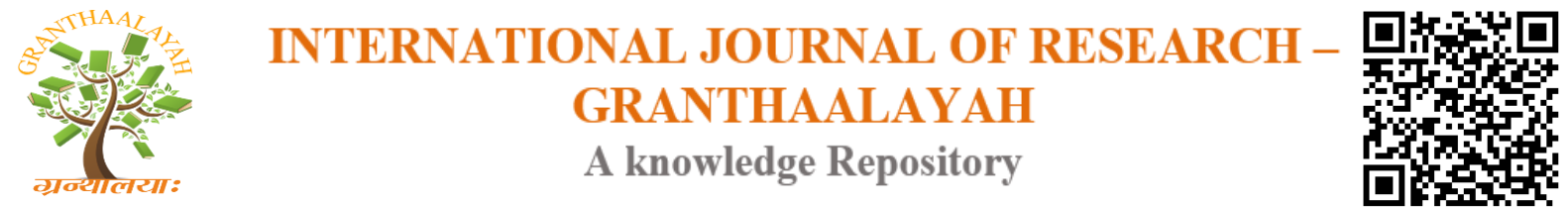

Management

\title{
USE OF ELECTRONIC JOURNALS IN ECONOMICS AND POLITICAL SCIENCE DEPARTMENTS IN DELHI UNIVERSITY: A COMPARATIVE STUDY
}

\author{
Dr. Javed Khan *1 \\ ${ }^{* 1}$ Assistant Professor, Swami Vivekanand Subharti University, Meerut, INDIA
}

DOI: https://doi.org/10.29121/granthaalayah.v4.i7.2016.2618

\section{ABSTRACT}

The main objective of present study is to compare the use of electronic journals by users in department of Economic and Political science in Delhi University. This investigation applied a standard survey method to analyse the use and utilization of e-journals. This study restricted only to the users of the Economic and political science department of Delhi University. Relevant literature on the e-journals use study has been reviewed. 150 users from both the department has been taken as sample for the study. The data was collected from the purposive sampling technique. The questionnaire was used as a tool of data collection. The data was analysed through percentage method. The main finding of the study is that the users of economics department use more E-journals in compare to Political Science department. Based on the results some suggestions have been made to the University to effective use of ejournals.

Keywords:

E-Journals, UGC-INFONET Journals, Open Access Journals, database.

Cite This Article: Dr. Javed Khan, "USE OF ELECTRONIC JOURNALS IN ECONOMICS AND POLITICAL SCIENCE DEPARTMENTS IN DELHI UNIVERSITY: A COMPARATIVE STUDY" International Journal of Research - Granthaalayah, Vol. 4, No. 7 (2016): 259-264.

\section{INTRODUCTION}

A journals or a periodical is based on scientific observation, investigation, or experimentation. Articles in journals include substantial bibliographies and are often peer received before research publication. Journals are sometimes called academic journals, scholarly journals, or professional journals. It occupies a very important position as primary tool for scientific communication. Scholarly journals survive because readers have confidence that the material published is accurate and timely. 


\section{TYPES OF E-JOURNALS}

Electronic journals come in many types. Some of them are traditional paper journals simply made available electronically: others are sample selections, or just the table of contents of the paper journal; still others have no equivalent paper copies. They can be broadly categories as follows.

1) Online Journals

2) CD-ROM Journals

3) Network Journals

- Online Journals: There in no university accepted definition journals. Somebody calls it as paperless journals, some scope say "virtual journals" and some say as "electronic journals" or "e-journals". Online journals are available through online hosts such as dialog. An online journal allows remote access. It can use simultaneously by more than one user. It provides timely access. Online journals support different searching capabilities and saves physical storage.

- CD-ROM: There are full texts journals published and distribute in the form of CD-ROM with regular updates, along with search software to access and print, like online journals the vast majority of CD-ROM based journals are the electronic versions of printed journals.

- Network Journals: Network e-journals are electronic journals available over network, such as internet, BITNET or any other commercial network. Examples of network ejournals are e-newsletters, e-discussions list.

\section{NEED FOR E-JOURNALS}

- Need to support parallel paper and electronic methods of knowledge dissemination.

- Information needed by faculty and students is increasing exponentially in the sciences.

- Interdisciplinary research / new fields of research have increased the scientist's need for new information.

- Significant increase in the speed of academic discourse can be achieved via electronic publication.

\section{REVIEW LITERATURE}

A survey conducted by Faizul and Naushad Ali (2013), revealed that most of the users are aware of e-journals and they are not only using them for building and updating their knowledge but also for collecting relevant material for their study and research purposes as information can be acquired expeditiously through e-journals. . Further by research Bakar and Araffin (2013) revealed electronic journals are widely used by lecturers and researchers in a public university in Malaysia. However, a research conducted by Baro et al (2011) at the Delta State University, revealed that electronic scholarly journal databases were underutilised. The users in the study cited the lack of awareness of the existing resources as the primary constraint they had. Similarly, empirical studies carried out by Rowlands (2007), Nicholas et al., (2008), Jamali, Nicholas and Huntington (2005), Davis (2004), Eason, Yu, and Harker (2000) showed that electronic journals have significant impact on researchers and scholars Voorbij and Ongering 
(2006) opined that researchers prefer searching to browsing in order to track down relevant articles.

\section{OBJECTIVES OF THE STUDY}

Following are the objectives of study:

- To find out the awareness and extent of use of e-journals in DU libraries.

- To find out the level of satisfaction with the use of e-journals subscribed by the library.

- To find out the frequency of using e-journals.

- To identify the problem being faced by the users while accessing e-journals.

\section{RESEARCH METHODOLOGY}

A well-structured questionnaire was designed to elicit the opinion of the users regarding use of ejournals. The questionnaires were personally distributed among 150 users of Economics Department and Political Science Department library out of 114 were return back duly filled. The data collected through the questionnaire was scrutinized classified and tabulation and presented with the help of percentage.

\section{DATA ANALYSIS AND INTERPRETATION}

Table 1: Awareness about Electronic Resources / Services

\begin{tabular}{|l|l|l|l|}
\hline S.No & Services & $\begin{array}{l}\text { Economics Deptt. } \\
\text { N=52 }\end{array}$ & $\begin{array}{l}\text { Political Deptt. } \\
\text { N=62 }\end{array}$ \\
\hline 1. & E-Books & $\begin{array}{l}42 \\
(80.76 \%)\end{array}$ & $46(74.19 \%)$ \\
\hline 2. & E-Journals & $26(50 \%)$ & $30(48.38 \%)$ \\
\hline 3. & E-Encyclopaedia & $14(26.52 \%)$ & $10(16.12 \%)$ \\
\hline 4. & E-Thesis & $6(11.53 \%)$ & $16(25.80 \%)$ \\
\hline 5. & E-Newspaper & $10(19.23 \%)$ & $4(6.45 \%)$ \\
\hline 6. & CD-ROM Databases & $10(19.23 \%)$ & $6(9.67 \%)$ \\
\hline 7. & Online Databases & $4(7.69 \%)$ & $10(16.12 \%)$ \\
\hline 8. & Internet & $38(73.67 \%)$ & $44(70.96 \%)$ \\
\hline 9. & OPAC & $22(42.30 \%)$ & $26(41.93 \%)$ \\
\hline 10. & E-Mail & $34(54.83 \%)$ & $38(61.29 \%)$ \\
\hline
\end{tabular}

This table shows that awareness about electronic resources / services economics department. Users $42(80.76 \%)$ aware about E-books $26(50 \%)$ aware about e-journals 14 (26.92\%) aware about E-Encyclopaedia $6(11.53 \%)$ aware about E-Thesis 10 (19.23\%) aware about ENewspaper 10 (19\%) aware about CD-ROM Database 4 (7.69\%) aware about online databases $38(73.07 \%)$ aware about internet $22(42.30 \%)$ aware about OPAC $34(54.83 \%)$ aware about EMail.

On the other hand Political Science department users 46 (74.19\%) aware about E-books 30 (48.38\%) aware about E-Journals 10(16.12\%) aware about Encyclopaedia 16(25.80\%) aware about E-Thesis $12(25.80 \%)$ aware about E-Newspaper 6(16.12\%) aware about CD-ROM 
Databases 6(9.67\%) aware about online databases 10(16.12\%) aware about Internet 44(70.96\%) aware about OPAC 26(41.93\%) and 38(61.29\%) aware about E-Mail.

Table 2: Satisfaction of user with the use of journal subscribed

\begin{tabular}{|l|l|l|l|}
\hline S.No & Satisfaction Level & $\begin{array}{l}\text { Economic Deptt. } \\
\text { N=52 }\end{array}$ & $\begin{array}{l}\text { Political Deptt. } \\
\text { N=62 }\end{array}$ \\
\hline 1. & Satisfied & $38(73.07 \%)$ & $32(51.61 \%)$ \\
\hline 2. & Dissatisfied & $14(26.92 \%)$ & $30(48.38 \%)$ \\
\hline
\end{tabular}

The table shows that users satisfied with journals subscribed in Economic Department library $38(73.07 \%)$ users and other hand $14(26.92 \%)$ are not satisfy with journal subscribed. One the other hand in Political Science department library 32(51.61\%) users satisfy with journal subscribed $30(48.38 \%)$ are not satisfied with journal subscribed.

Table 3: Frequency of using Internet, E-Journals

\begin{tabular}{|l|l|l|l|}
\hline S.No & Frequency Using & $\begin{array}{l}\text { Economic Deptt. } \\
\text { N=52 }\end{array}$ & $\begin{array}{l}\text { Political Deptt. } \\
\text { N=62 }\end{array}$ \\
\hline 1. & Daily & $4(7.69 \%)$ & $10(16.12 \%)$ \\
\hline 2. & 2/3 Times a Week & $34(65.38 \%)$ & $42(67.74 \%)$ \\
\hline 3. & 2/3 Times in a Months & $38(73.07 \%)$ & $26(41.93 \%)$ \\
\hline 4. & Only a Month & $8(15.38 \%)$ & $18(29.03 \%)$ \\
\hline 5. & Occasionally & $2(3.84 \%)$ & $6(9.67 \%)$ \\
\hline
\end{tabular}

The table-3 shows that the 4 (7.69\%) Economics Department use daily and $34(65.38 \%) 2 / 3$ Times in a Week $38(73.07 \%)$ 2/3 Times in a Months and $8(15.38 \%)$ are using only a Month and Occasionally $2(3.84 \%)$ are using frequently.

One other hand Political Science Department use daily and $10(16.12 \%)$ 2/3 Times in a Week 42 (67.74\%) 2/3 Times in a Months and 26 (41.93\%) are using only a Month and 18 (29.03\%) Only a Month's and Occasionally 2(3.84\%) are using frequently.

Table 4: Problem Faced While Using E-Resources

\begin{tabular}{|l|l|l|l|}
\hline S.No & Problem Faced & $\begin{array}{l}\text { Economic } \\
\text { N=52 }\end{array}$ & $\begin{array}{l}\text { Political Deptt. } \\
\text { N=62 }\end{array}$ \\
\hline 1. & Lack of Time & $26(50 \%)$ & $18(29.03 \%)$ \\
\hline 2. & Uncomfortable & $14(26.92 \%)$ & $6(9.67 \%)$ \\
\hline 3. & What to Look For & $4(7.69 \%)$ & $2(3.22 \%)$ \\
\hline 4. & Not Easy to Use & $32(51.61 \%)$ & $26(41.93 \%)$ \\
\hline 5. & No Knowledge of Using & $34(54.83 \%)$ & $22(35.48 \%)$ \\
\hline 6. & Access time is Slow & $18(34.61 \%)$ & $10(16.12 \%)$ \\
\hline
\end{tabular}

The table-4 shows that the problem faced using the electronic resources Economics Department $26(50 \%)$ users for use lack of time and 14 (26.92\%) for using Uncomfortable 4 (7.69\%) for use what to look for and $32(51.61 \%)$ for not easy to use $34(54.83 \%)$ for no Knowledge of using and $18(34.61 \%)$ for access time is slow. 
On the other in Political Science Department 18 (29.03\%) users for use lack of time and 6 (9.67\%) for use uncomfortable $2(3.22 \%)$ for use what to look for and $26(41.93 \%)$ for not easy to use $22(35.48 \%)$ for no knowledge of using and $10(16.12 \%)$ for access time is slow.

\section{FINDING OF THE STUDY}

1) Mostly of the users are aware about E-books available in the library.

2) Majority of the library users are satisfy with journal subscribed.

3) High percentages of the Economics department users are use Internet, CD-ROM services and e-journals 2/3 times in a months and Political Science department users 2/3 times in a week.

4) Majority of the users are facing the problems while using electronic resources is not easy to use.

\section{CONCLUSION}

The present study was conducted on the use of e-journals by the users working in the selected present age, when the volume of scientific literature is increase immensely every day. The prices of the journals are spiraling higher and specially with emergence of multidisciplinary and interdisciplinary subjects. Hence, adequate selected subscription of e-journals seems to be the solution. This study has shown that users are well aware about e-journals service provided by the libraries and e-journals are playing a very important role in their research, teaching and training. Therefore, there is need to subscribe more multidisciplinary e-journals by their respective libraries.

To summaries it is the challenges for library and librarians as to how they are offering services to their users. The study has shown that there is a need to enhance more awareness about the usage of e-journals for that there is a need for workshop. Information literacy programmers, so that users know how to use e-journal. Being a part of agriculture consortium, libraries can improve their services, as they will be able to provide more subject oriented e-journals. Libraries must keep the users up to date with the current information by sending them e-mail alert about the new e-journals subscribed by the library and also display that on library web page.

\section{SUGGESTIONS}

1) The library should increase the bandwidth to ensure faster access to e-journals.

2) The library should promote the use of e-journals through various promotional activities.

3) To reduce slowly down loading problem while accessing the e-journals the digital library should acquire high speed Internet and Intranet connections.

4) Number journals available through consortia may be increased to access to more journals in their respective fields.

\section{REFERENCES}

[1] Kumber, B.D and Hadagali, G (2009) "Use of UGC Infonet E-Journals consortium by faculty members and research scholars of Karnatak University Dharwad: A study" SRELS Journals of Information Management, Vol 46, No1, PP. 61-72. 
[2] Trivadi, Mayank and Joshi Anuradha (2009) "Usage of electronic journals versus print journals by health care professionals in H.M.Patel centre for medical care and education (HMPCME) "Journals of Health Informatics in Developing Countries Vol.3 No. 1 PP. 13-16.

[3] Moghaddam, Golnessa and Talwar, V (2008) "The use of scholar electronic journals at the Indian Institute of Science: A case study in India” Interlarding and document supply, Vol. 36 No.1 pp. 15-29.

[4] Kumbar B.D and Seema. P (2007) "Use of periodicals literature in the university of agriculture sciences Daharwad: A case study" Desidoc Bulletin of Information Technology, Vol. 27 No.2 pp. 37-47.

[5] Ahamad, Moin and Haridasan, Sudharma (2006) "Use of periodicals by the scholars at national library of veterinary sciences: A users study” (IASLIC) bulletin Vol. 51, No.2. pp. 1-17.

[6] Raza, M.M. and Upadhaya A.K (2006) "Usage of e-journals by Research Scholar in Aligarh Muslim University: A case study" The International Information and Library Review Vol. 38 No.3 PP.1701-179. 